\title{
THE PROTECTION PROVIDED BY INTERNATIONAL REFUGEE ORGANIZATIONS IN TURKEY IN THE IMMEDIATE POST-WAR PERIOD
}

\author{
Karolina Wanda Olszowska
}

http://orcid.org/0000-0003-0535-912X

Jagiellonian University, Kraków

\begin{abstract}
In Turkey, during the Immediate Postwar Period (between 1945-1951), functioned the international specialization organizations, such as the United Nations Relief and Rehabilitation Administration (UNRRA), the Intergovernmental Committee on Refugees (IGCR) and the International Refugee Organization (IRO). Turkey was a country of minor importance in terms of the number of refugees in this period. According to data from IGCR, in 1946, there were 1221 registered refugees in Turkey. Among them were representatives of different nationalities, such as Poles, Yugoslavs, Albanians, Hungarians, Czechoslovaks, Austrians, Germans and Jews of various ethnicities. Later joined by Bulgarians and other anti-communist activists. The international specialization organizations faced various problems, from lack of money to the lack of cooperation from the Turkish government. IRO activists often complained about the sluggishness of Turkish officials. The problematic is important as an exemplification of the question of the protection of refugees by the International Community.
\end{abstract}

Keywords: Turkey, refugees, International Refugees Organization, IRO.

The purpose of this paper is to analyse the protection provided for refugees in Turkey during the immediate post-war period, i.e. between 1945 and 1951, by international specialised organisations such as the United Nations Relief and Rehabilitation Administration (UNRRA), the Intergovernmental Committee on Refugees (IGCR) and the International Refugee Organization (IRO). UNRRA was an international aid organisation. It was founded in 1943, but in 1945 became a part of the United Nations and, two years later, was replaced by IRO. The International Refugee Organization was the first international agency created by the United Nations Organization. It was 
active between 1947 and 1952. ${ }^{1}$ IRO is known as an organisation providing aid for refugees, which was particularly active in the British, French and U.S. occupation zones of Germany and Austria as well as in Italy. Turkey was another country where IRO established a presence, albeit on a much smaller scale. Despite this fact, Turkey is interesting and little-known example of IRO activity.

\section{REFUGEES FROM THE BOSPORUS REGION IN HISTORY}

Large-scale refugee movements began in the $19^{\text {th }}$ century. Between 1821 and 1922 roughly 5 million Muslims emigrated from the Balkan Peninsula and the coast of the Black Sea. Between 1878-1913 1.7-2 million people left the European part of the Ottoman Empire. ${ }^{2}$ After the Balkan wars (1912-1914), thousands of Turks, Greeks and Bulgarians were driven from their homes. Under the provisions of the Treaty of Lausanne (1923) 1,300,000 Greeks were transferred from Asia Minor to Greece, while 400,000 Turks were moved from the Balkans to Turkey. ${ }^{3}$ In the Balkans, migrations were an influential factor in the formation of nation states.

In 1920, Istanbul provided a sanctuary for members of the White Russian émigré community who had managed to escape from Russia. These refugees included "white" Russian officers who were waiting to resume the fight with the Bolsheviks, as well as the old aristocracy who had been forced to leave homeland in fear of their lives. For the most part they lived in poverty after having sold out all their furs and jewellery. ${ }^{4}$ However, there were also cases of Russian refugees with a completely different political complexion. The most prominent ex-Bolshevik dissident to find refuge in Turkey was Leon Trotsky.

During the World War II, Turkey was formally a neutral country. In practice, however, İsmet İnönü, the second president of Turkey, performed a smart balancing between both sides of the conflict. This policy also affected the treatment of refugees in Turkey. The first German refugees arrived in the country after 1933. Approximately 150 Germans had fled their country due to political, racial or religious persecution. They had been stripped of their German citizenship due to racial laws or because they were political opponents of Nazism. These Germans were classed by the Turkish authorities as "Heimatlose" ("stateless persons"). At the same time, however, Turkey

1 L. W. Holborn, The International Refugee Organization: A Specialized Agency of the United Nations, London-New York-Toronto 1956. See also: P. Sękowski, "Activity of the International Community in Europe after the Second World War within the Scope of the International Refugee Organization as a Model of the Aid Action towards Refugees," Securitologia 2017, no. 3.

2 K. Karpat, Studies on Ottoman Social and Political History, Leiden-Boston-Koln 2002, p. 321.

L. W. Holborn, The International Refugee Organization, p. 3.

4 C. King, O pótnocy w Pera Palace. Narodziny wspótczesnego Stambułu, transl. J. Hunia, Wołowiec 2016, pp. 105-106.

5 In international law, a stateless person is someone who is "not considered as a national by any state under the operation of its law." Some stateless persons are also refugees. However, not all refugees are stateless, and many persons who are stateless have never crossed an international border. 
also played host to Germans who had come at the invitation of Ankara Government as employees or officials in the country. They maintained their German citizenship, but after 1944 few of them wished to return to Germany. The rest wanted to remain in Turkey. ${ }^{6}$

During the World War II, Turkey offered refuge to victims of the Nazi regime, who had fled due to ill-treatment for racial and political reasons. During this time many Jews reached Turkey from France, Romania and other countries, some of them only passing through Turkey on their way to Palestine. In the years 1943-1945, 13,101 Jews came to Palestine via Turkish territory. It is estimated that over $1 / 4$ of the Jewish refugees who emigrated to Palestine during the World War II passed through Istanbul. ${ }^{7}$ However, not all Jewish people who reached Turkey were lucky enough to reach their final destination, for example, the passengers of the Struma ship. The Struma was taking nearly 800 Jewish refugees from Romania to Palestine, when its engines failed and she was towed to Istanbul. British diplomats feared the Arab reaction in Palestine and this was the main reason why Great Britain refused to issue visas to the Jews. Subsequently Struma was towed through the Bosporus and out into the Black Sea, where the next day it was torpedoed and sunk by a Soviet submarine. A total of 768 people lost their lives in this catastrophe, and only one man, David Stoliar, was saved. ${ }^{8}$

On the other hand, in the last months of the war and in its immediate aftermath, many Turkish Jews left Turkey due to the considerable negative impact of the capital tax (Varlık Vergisi) imposed on the local Jewish population by the Turkish government in 1942. This tax was in theory levied on all citizens of Turkey, but in actual fact non-Muslims paid approximately 53\% of the total amount (Turkish Muslims contributed $36.5 \%$ of the total while non Turkish citizens accounted for the remaining $10.5 \%) .{ }^{9}$ Large numbers of non-Muslim Turkish citizens lost all their property as a result and after the World War II decided to emigrate to a different country, as obviously such a decisions had not been taken by concerned people during the hostility.

\section{THE INTERNATIONAL REFUGEE ORGANIZATION IN TURKEY}

The International Refugee Organization opened its office in Istanbul in July 1947 and closed it in March 1951. On 25 June 1948 an agreement was signed in Geneva between the government of the Turkish Republic and the preparatory commission of the International Refugee Organization regarding the immigration of displaced per-

${ }^{6}$ Archives Nationales de France, Pierrefitte-sur-Seine (later: AN, France), Archives of the I.R.O. AJ 43 (later: AJ 43)/1069, Report of Elisabeth Brown representative for UNRRA in Palestine and Levant States, Cairo, 18 July 1946, p. 4.

7 C. King, O pótnocy w Pera Palace, p. 361.

8 D. Frantz, C. Collins, Death on the Black Sea: The Untold Story of the Struma and World War II's Holocaust at Sea, New York 2003, p. 198.

9 S. J. Shaw, E. K. Shaw, Historia Imperium Osmańskiego i Republiki Tureckiej 1808-1975, transl. B. Świetlik, Warszawa 2012, p. 603. 
sons into Turkey. ${ }^{10}$ The organization's work in Turkey was overseen by the IRO Mission located in Cairo. Earlier, the International Rescue Committee had been active in Turkey, with Floyd Black acting as its chairman from October 1946. ${ }^{11}$ Under the Constitution of the International Refugee Organization refugees and displaced persons were assigned IRO protection. The refugees that met the criteria of IRO protection where called 'eligible refugees. ${ }^{12}$ Later, displaced persons were also referred to as refugees. Although Turkey had relatively few refugees under IRO protection, this did not mean that there were not many refugees in the country in general at this time, but rather that only some of them met IRO criteria. Most of the refugees who came to Turkey had Turkish origins (such as Bulgarians) or were given Turkish citizenship. Turkey also tended to be a country of transit (among others, for Jews heading to Palestine) rather than a final destination. The Turkish government tried to maintain full freedom in its refugee policy. One important and exceptional feature of this policy is that on arriving in the country refugees almost automatically received Turkish citizenship, after arriving in the camp their Bulgarian passports and Turkish visas were examined, they completed forms for registration of Turkish citizenship, ${ }^{13}$ and for this reason the Turkish government believed that further IRO care was unnecessary.

According to a report from October 1946, there were 1221 displaced persons registered as under UNRRA protection in Turkey at this time. According to this report, the largest group comprised Germans from Germany (approximately 500 people), followed by Poles (105 persons), Yugoslavs (96), Albanians (69), and Hungarians (16). Approximately 100 displaced persons were Czechoslovaks whose citizenship had been revoked or challenged, while another approximately 150 were Austrians. However, at this time neither Austrian or Czechoslovak citizenship was recognized, as Austria and Czechoslovakia constituted a part of the Third Reich from before the World War II. ${ }^{14}$ Additionally, 145 Jews with Turkish citizenship and 40 Jews repatri-

10 AN, France, AJ 43/1060, Agreement between the government of the Turkish Republic and the preparatory commission for the International Refugees Organization relative to the immigration of displaced persons into Turkey, Geneva, 25 June 1948, p. 8.

11 AN, France, AJ 43/52, International Rescue and Relief Committee, Istanbul Branch Report on Activities during 1945/1946, [Istanbul], 10 August 1946, p. 2.

12 According to Constitution of the International Refugee Organization the term "refugee" applies to a person who has left, or who is outside of, his country of nationality or of former habitual residence, and who, whether or not he had retained his nationality, belongs to one of the following categories: (a) victims of the nazi or fascist regimes or of regimes which took part on their side in the World War II, or of the quisling or similar regimes which assisted them against the United Nations, whether enjoying international status as refugees or not; (b) Spanish Republicans and other victims of the Falangist regime in Spain, whether enjoying international status as refugees or not; (c) persons who were considered refugees before the outbreak of the World War II, for reasons of race, religion, nationality or political opinion. The term "displaced persons" were people who, due to the war and decision of the occupational authorities - particularly forced labor deportations -, had found themselves outside borders of the country of their pre-war residence. L. W. Holborn, The International Refugee Organization, pp. 584-585.

13 H. L. Kostanick, "Turkish Resettlement of Refugees from Bulgaria, 1950-1953," Middle East Journal 1955, vol. 9, no. 1, p. 48.

14 In September 1938, Adolf Hitler demanded control of the Sudetenland, accepted by France. Great Britain and Italy in the Munich Agreement. During October 1938, Nazi Germany occupied and annexed 
ated from the Bergen-Belsen Concentration Camp, where camp prisoners from all over Germany were brought together in 1944/45, were also classified as displaced persons in Turkey. ${ }^{15}$ According to a UNRRA report dated 18 July 1946, approximately 185 Jews were living in Turkey at that time. ${ }^{16}$

It is worth noting that only a relatively small number of refugees were ever under the care of the UNRRA and later the IRO. This was due to many factors, the most important of which was that many of those who came from the Balkans had Turkish origins, and thus did not fall under the aegis of UNRRA/IRO. In addition, the Turkish government awarded other refugees Turkish citizenship after a provisional period (i.e. after one year), as a result of which they then ceased to be under IRO protection. The latter was the main reason why relatively few refugees were under the care of IRO. On the other hand, Jews who travelled through Turkey on their way to Palestine were not included in Turkish UNRRA/IRO documents, even if this organization paid for their journey. Only refugees and displaced persons were eligible for formal assistance from IRO, which is why, despite the large numbers of people who had come to Turkey since the beginning of the $19^{\text {th }}$ century, only a relatively small number were assisted by the international community after the war.

According to a report from March 1947, 95 persons cared for by IRO in Turkey were in a critical situation. All of these cases had to be considered individually, and money was allocated to cover school fees for children, sickness allowance etc. This approach was necessary because IGCR aid to Turkey was insufficient. The abovementioned group of special cases included 26 Albanians, 29 Austrians, 17 Germans, 3 Poles and 20 Yugoslavs. ${ }^{17}$ To ensure money for them, the International Rescue Committee contacted the British Ambassador in Ankara with a request to transfer the sum of 1,000 pounds per month. According to calculations made by this organisation, the total sum needed to cover the needs of these 95 individuals was 3,790 pounds a month. ${ }^{18}$ In terms of expenditure, the most costly national group in this category were the Poles, who required the sum of approximately 67 pounds per person per

the Sudetenland border region, effectively crippling Czechoslovak defenses. On 15 March 1939, the remainder of Czechoslovakia was invaded and divided into the Protectorate of Bohemia and Moravia and the puppet Slovak State.

In early 1938, the government and the president of Austria resisted the seizure of power by the local Nazis. On 9 March 1938 Chancellor Kurt Schuschnigg announced a referendum on 13 March in which the Austrians would speak on the future of their country. In this situation, on Hitler's order on 12 March 1938 Wehrmacht entered Austria. On 13 March the Austrian Nazis announced a bill approved by Hitler, which included Austria into the Great Reich as the Eastern March (Ostmark). To finally seal the "unification" of Austria with the Reich, Hitler set a plebiscite on 10 April 1938. According to an official announcement issued on 11 April 1938, 99\% of votes were cast in Germany, and 99.7\% in Austria. Great Germany was recognized, among others, by Great Britain and France.

15 Ibid, p. 3.

16 AN, France, AJ 43/1069, Elizabeth Brown Representative for UNRRA in Palestine and Levant State to Deputy Chief MEO, Istanbul, 18 July 1946, p. 1.

17 AN, France, AJ 43/52, Letter for sir Herbert Emerson director of Intergovernmental Committee on Refugees in London, Ankara, 1 March 1947, p. 1.

18 Ibid, p. 2. 
month. The cheapest to maintain were the Austrian refugees at 29 pounds per person per month. ${ }^{19}$

Of the eighteen Poles whose material situation was poor, 3 individuals - M. Ibrahimon Rifat and two members of his family - were in a critical situation. ${ }^{20}$ Only roughly $8 \%$ of the refugees on the list established by IGCR. This was due to the fact that many refugees who came to Turkey were educated and thus quickly found employment. Most of those in a state of destitution had previously worked for governments "in exile," and after the war had lost their means of subsistence.

\section{POLISH REFUGEES IN TURKEY}

In the $19^{\text {th }}$ century, Polish insurgents and deserters from the Russian army found shelter in the Ottoman Empire. In 1842, a Polish village, Adampol (Polonezköy) was founded near Istanbul. During the World War II (in October 1939) the chief headquarters in Ankara gave the evacuating Polish army permission to cross the Straits. Polish officers and non-commissioned officers were transported across Turkish territory to Beirut or the Pyrenees, but their families remained in Turkey. In December 1939, 24 Polish engineers residing at that time in Romania obtained employment in Turkey. ${ }^{21}$

In August 1945 the Turkish Government formally recognized the Polish Government in Warsaw, and ipso facto the Polish Embassy in Ankara (headed at that time by Ambassador Michał Sokolnicki) and also the Polish General Consulate in Istanbul (the Consul General was Witold Korsak) ceased to exist. ${ }^{22}$ Some days earlier, the Counsellor at the British Embassy in Ankara, Alexander Helm, declared that the British should stop providing financial support for the diplomats of the Polish Government-in-exile, including the Polish Embassy in Turkey and its staff. ${ }^{23}$

At the beginning of 1946 the Turkish Government was confronted with the need to deal with a group Poles opposed to the new Warsaw regime because the Warsaw Chargé D'affaires in Ankara did not want to look after them. The Turkish Government informed London that employing and accommodating them was problematic and the British considered transferring these Polish refugees to Lebanon. ${ }^{24}$ The Polish Chargé d'affaires distributed relief to those refugees who signed a declaration of loyalty to the new regime and declared a desire to return to Poland. One of the Poles who

19 Author's own calculations.

20 AN, France, AJ 43/52, List of the Polish refugees in the tragic situation, Ankara, 1 March 1947, p. 1.

${ }_{21}$ The Polish Institute and Sikorski Museum in London (later: PISM, London), Sztab NW i MSWojsk/ MON, 1939-1948 (later: A 12)/60/1, Reports from Polish Embassy in Ankara to Polish Government-inexile, October-December 1939.

22 PISM, London, A 12/24, Telegraph for Mr. Buczyński, May 1945, p. 8.

23 M. Sokolnick i, Ankarski dziennik 1943-1946, Londyn 1974, p. 369.

24 The National Archives in London (later: AN, London), Foreign Office - FO 371 (later: FO 371)/56603, Reports with telegrams to London about Poles refugees in Turkey, 3 February 1946, p. 2. 
thus found themselves on the above-mentioned critical list was Witold Korsak, the Polish diplomat who, during the World War II, had acted as Polish Consul General in Jerusalem, and later also in Beirut and Istanbul. On 24 July 1948, Turkey and Poland signed Commercial and Payments Agreements..$^{25}$ These economic concords had no impact on the plight of the Polish refugees in Turkey. According to a report from 21 June 1949, there were 5,438 Polish refugees in the Middle East at the time. Three hundred and thirty of them lived in Turkey, 237 of whom were considered employable according to IRO criteria, 61 deemed borderline cases, and 32 as unemployable, and treated as "hard core cases," i.e. people who, mainly due to disability or old age, were the most problematic group under IRO care in terms of their chances of eventual resettlement abroad. ${ }^{26}$ There were many Poles in Turkey who sympathised with the former Polish and Yugoslav Governments in exile (for example, consular and embassy staff members and auxiliary personnel); practically all these Poles were either refugees with Polish nationality or stateless persons of Polish origin.

\section{WHEN ONE DAY YOU HAVE YOUR OWN COUNTRY AND THE NEXT YOU BECOME A DISPLACED PERSON}

Many Poles, Yugoslavs and Albanians did not want to go back to their homelands. Most Yugoslavs had arrived in Turkey before the war and they held passports of the Kingdom of Yugoslavia. As a consequence, later they theoretically became stateless. ${ }^{27}$ Many Yugoslavs had families with Turkish citizenship and their only desire was for some kind of legal and political protection. All the Yugoslavs who were included on the IRO lists were also registered by the Royal Yugoslav Free Committee in Istanbul and were in police records, too. In the case of the Albanians, they fled to Turkey in 1939 after their country was attacked by Fascist Italy. Hungarians, on the other hand, were political refugees but were not classified as dissidents. The Austrians and Czechoslovaks faced a different problem: when they arrived in Turkey they held German citizenship (it is irrelevant that these two groups obtained German citizenship in different ways). Most Germans from Third Reich proper were sent to the Turkish region of Anatolia.

A number of observations should be made about the ethnic composition of the refugees in Turkey over the next few years. The nationalities mentioned above were joined by new groups: Bulgarians (298 arrivals in July 1949 and 320 in August 1949), Poles (22 arrivals in July 1949 and 25 in August 1949), Russians (16 in July and 21

25 AN, London, FO 371/72551, Documents from British Embassy in Ankara about Polish-Turkish Agreement, Ankara, 13 August 1948, p. 2.

26 AN, France, AJ 43/1065, Report for The Under Secretary of State for Foreign Affairs Foreign Office in London, 21 June 1949, p. 84.

27 AN, France, AJ 43/194, Narrative Report, Legal and Political Protection, Istanbul, 7 March 1950, p. 10. 
in August, respectively), Ukrainians (5 arrivals) and Georgians (2 arrivals) ${ }^{28}$ During this period Bulgarians constituted the largest group of refugees. Excluding this latter group, only a small number of people in Turkey fell under IRO protection. However, it is interesting to note that the IRO began to cater for an increasing number of Poles and Russians and that the largest group of refugees at that time were Poles.

\section{PROBLEMS AFFECTING BULGARIAN REFUGEES}

Bulgarians of Turkish origin form a very interesting category. Officially, they were not under IRO protection, because the Turkish government had granted them Turkish citizenship. Nevertheless, the IRO meticulously reported their situation and it was also via this organization that funds were transferred from the USA.

The Bulgarian government willingly issued passports to anyone who was of Turkish origin (i.e. to. members of the Turkish minority in Bulgaria). In August 1950 the Bulgarian government sent a diplomatic note to the Turkish Ambassador in Sofia referring to the old Turkish-Bulgarian Treaty of Friendship of 18 October $1925 .{ }^{29}$ One part of this treaty concerned a population exchange between Turkey and Bulgaria.

Theoretically, leaving Bulgaria was voluntary. However, the Bulgarian government pressed Turkey to accept 250,000 refugees over a period of just three months. A large number of applicants did not receive Turkish visas. In August 1950 the Turkish consulate in Sofia issued 54,000 visas..$^{30}$ Bulgaria wanted to send people without the necessary papers, solely on the basis of the 1925 Treaty. Therewith, on $7^{\text {th }}$ October 1950, the Turkish-Bulgarian border was closed. It was the beginning of a diplomatic game between Ankara and Sofia. Turkey did not have any solution to the problem. They lodged protests with the United Nations and the Council of Europe. However, these bodies did not take any further action. ${ }^{31}$ The Bulgarian government wanted to open the Turkish border again, but the Turkish side set one condition: the border between Bulgaria and Turkey could only be crossed by people in possession of a Turkish visa. The refugees felt aggrieved and organized demonstrations. The Grand Mufti remonstrated with the Turkish legation in Sofia. ${ }^{32}$ The Bulgarian government was forced by the situation to provide shelter and prepared a camp by the Turkish border.

28 AN, France, AJ 43/797, Breakdown by Nationalities of eligible refugees living in Turkey 31 August 1949, p. 27; AN, France, AJ 43/797, Breakdown by Nationalities of eligible refugees living in Turkey 31 July 1949, p. 28.

29 D. Bay1r, Minorities and Nationalism in Turkish Law, London-New York 2013, p. 88.

30 AN, France, AJ 43/430, High Commissioner's Advisory Committee for Refugees, Provisial Agenda, Refugees from Bulgaria in Turkey, 25 July 1952, p. 2.

31 AN, France, AJ 43/1093, The Mohamedan-Turkish Minority from Bulgaria, Istanbul, 21 November 1950 , p. 1.

32 R. L. Wolff, The Balkans in Our Time, Cambridge 1974, p. 478. 
In October 1950 the Bulgarian Red Cross spent 1,202,493 lev on supplying these people with food, money, medicines etc. ${ }^{33}$

Political talks lasted two months before the border was finally re-opened on $5^{\text {th }}$ December 1950. In the following year, the visa problem re-emerged. The new Bulgarian regime believed that Bulgarian citizens should be Christian in origin and culture and that their mother tongue must be Bulgarian. Everybody else should leave the country. Many people were ordered, against their will, towards the Turkish border. Eventually, the Turkish border was closed once more on 8 November 1951. By that time, 154,393 individuals had arrived in Turkey via this route. ${ }^{34}$ This state of affairs persisted until 26 February 1953. The Turkish authorities were reluctant to resume the reception of large numbers of new refugees because of the vast expenditure this had already entailed..$^{35}$

Most Bulgarian citizens of Turkish ethnicity very quickly decided to seek opportunities to move to Europe or Canada. People who wanted to stay in Turkey and who had a Turkish visa and a Bulgarian passport were finally issued a residence card for one year. During these 12 months, card holders were exempt from tax and expected to assimilate. The Bulgarian refugees were in an easier position than other refugees because the Bulgarian nationals were until then of Muslim faith and in Francis Blanchard's opinion the Turks were willing to grant them Turkish citizenship. ${ }^{36}$ On the other hand, the arrival of so many Bulgarian migrants also had benefits for Turkey. For example, overall, the Bulgarian immigrants were more skilled, better educated and generally more effective than the average worker in Turkey.

Apart from Bulgarian refugees, only a small number of people in Turkey fell under IRO protection. However, it is interesting to note that the IRO began to cater for an increasing number of Poles and Russia and that the largest group of refugees at that time were Poles (displacing refugees of Turkish origin from Bulgaria).

\section{THE SITUATION OF THE REFUGEES UNDER IRO PROTECTION IN TURKEY}

During their stay in Turkey, refugees were monitored by the Turkish police. This was in actual fact a very complicated process. Theoretically, certain categories of immigrant were barred from entry into Turkey, such as: those who had no links with Turkish culture, anarchists, spies, nomadic gypsies and finally, those who had been

33 The Turkish Minority in The People's Republic of Bulgaria, Sofia 1951, p. 45.

34 AN, France, AJ 43/430, High Commissioner's Advisory Committee for Refugees, Provisial Agenda, Refugees from Bulgaria in Turkey, 25 July 1952, p. 4.

35 D. Vasileva, "Bulgarian Turkish Emigration and Return," International Migration Review 1992, no. 26, p. 46.

36 AN, France, AJ 43/1093, Report from Francis Blanchard to sir Arthur Rucker, New York, 1 November 1950, p. 30. 
previously expelled from Turkey. ${ }^{37}$ Three of these five groups (spies, former expellees from Turkey and anarchists) were undesirables for obvious political reasons. Nomadic gypsies were not welcome because of their non-sedentary lifestyle. Although Nomadic tribes (among others, Yürüks) had lived in Turkey for centuries, during the period in question, Turkish authorities were trying to make these tribes settle down. As a consequence, nomadic gypsies were among those immigrants who were denied entry to Turkey. The most astonishing category of undesirables were those with no links with Turkish culture. This category was interpreted arbitrarily by the authorities. It mainly concerned toe Bulgarian refugees of Turkish origin, and it did not refer to other refugees, such as those from Germany, Poland or Czechoslovakia.

The status of refugees in Turkey was somewhat complex. Luckily, the number of such persons in the country was relatively small. Despite this fact, however, many refugees were unemployed and lived in bad conditions. Coincidentally, several winters during this period were very cold and snowy. Refugees lacked suitable attire for these conditions, and often had no change of clothes. Furthermore, some refugees arrived in military uniforms which they could not wear in Turkey. ${ }^{38}$ Employment posed another problem because although it was not very difficult to find a job, nationalist feelings were very strong at the time and it was not easy for immigrants to obtain permanent work..$^{39}$ Many refugees became homeless and lived on the streets of Istanbul. The worst period of the year was October and November, when the unemployment rate was highest. The International Refugee Organization helped these people to find accommodation in whatever hotels or hostels were available. Refugees received $0.5 \mathrm{~kg}$ of bread per day and any hot meals and clothing were delivered by the Turkish Red Crescent (Türk Klzll Ayl).

According to one report, no orphaned children were registered under IRO protection in Turkey, although 10 children were of school age. IRO was mainly financed by USA, Great Britain and France, and young refugees had an opportunity to obtain a scholarship at the American Robert College and the French Legation School in Turkey. ${ }^{40}$ Both were very good and expensive schools. Many young refugees had a strong desire to continue their education and later pursue careers thanks to their qualifications. However, these young people encountered problems in other countries, because certificates from Turkish Universities were recognised in very few countries.

A document entitled Welfare in Turkey after the Cessation of I.R.O. Activities on March 31, 1951 provides a statistical breakdown of refugees in Turkey. During this period 300 persons were registered in IRO records (this figure does not include refugees who were exclusively and definitely entitled to Legal and Political Protection Only). Of this total 22 individuals were aged $0-16$ years, 239 persons were aged

37 AN, France, AJ 43/430, High Commissioner's Advisory Committee for Refugees, Provisial Agenda, Refugees from Bulgaria in Turkey, 25 July 1952, p. 5.

38 AN, France, AJ 43/797, Welfare in Turkey after the Cessation of I.R.O. Activities on 31 March 1951, p. 11.

39 AN, France, AJ 43/1060, Report for Arthur Rucker in Geneva, 12 April 1948, p. 33.

40 AN, France, AJ 43/797, Welfare in Turkey after the Cessation of I.R.O. Activities on 31 March 1951, p. 16. 
16-50 and 39 aged over 50. As regards their religion, 180 were Orthodox Christians, 72 Roman Catholics, 11 Protestants and 37 Muslims. The group comprised 247 males and 53 females. One hundred and 6 persons were single. 87 were married but had left their families behind, 37 were married and had come with their families, 6 were divorced and 4 were widowers. Finally, in terms of profession 123 were farmers, 54 were members of the intelligentsia, 47 were specialists, 26 were artisans and 33 were housewives. ${ }^{41}$ At the same time, the total number of all refugees registered with the Turkish IRO was $681 .{ }^{42}$

IRO experienced major problems with the Turkish Government. The official status of IRO in Turkey remained ambiguous. An agreement between the government of the Turkish Republic and the preparatory commission for the International Refugees Organization was signed in 1948. At the same time, Turkey was reluctant to be a member of the IRO (due to its poor economic situation) and did not want to recognize IRO's presence in Istanbul. In IRO's opinion, Turkish bureaucracy was slow and cumbersome and different cases dragged out over months. However, in other documents (H. Wilbrandt's 1950 report for J. D. Kingsley), we learn that because the IRO's presence in the country was not officially recognised by the Turkish Government, IRO provided less legal protection in Turkey than elsewhere. ${ }^{43}$ From these sources it can be deduced that while the Turkish government wanted IRO financial support for refugees, ${ }^{44}$ it impeded its legal activity and resisted any political influence on Turkish territory. The authorities in Ankara refused to submit reports on the situation of refugees in country. They claimed that the latter had been awarded Turkish citizenship and thus were no longer under the care of IRO. Another interesting aspect of the IRO's relationship with Turkey was the IRO's attempt to convince the Turkish authorities to continue their role as defender of the interests of all Muslim refugees under the IRO's mandate. However, this idea was never pursued in practice due to Turkey's failure to join the IRO.

There were many other organizations active in Turkey at this time, for example the Turkish Red Crescent, Gö̧̧men ve Mültecilere Türkiye Yardım Birliği (Turkish welfare organization for refugees and migrants), the Roman Catholic Organization, Orthodox Organization and the World Council of Churches. These bodies also offered support and protection for refugees. The Turkish government exploited the rivalry between them to limit their rights and autonomy. For this reason, the IRO's ability to function in Turkey was restricted.

${ }^{41}$ AN, France, AJ 43/797, Welfare in Turkey after the Cessation of I.R.O. Activities on 31 March 1951, p. 21.

42 AN, France, AJ 43/797, Master List of Refugees in Turkey Registered with the International Refugees Organization as of 1 April 1951, p. 25.

43 AN, France, AJ 43/194, Report IRO Turkey Office for D. Kingsley, Istanbul, 11 August 1950, p. 2.

44 Ibid. 


\section{CONCLUSION}

The International Refugee Organization was active in Turkey but on a much smaller scale than in other countries. What is important is that refugees in Turkey had a very distinct status and specific characteristics compared with other countries. For example, among the groups under IRO protection in Turkey, for instance, were numerous Bulgarian refugees of Turkish ethnicity who had been forced by the Bulgarian authorities to leave their country and move to Turkey. Turkey is a very interesting example because almost immediately after their arrival the government granted refugees Turkish citizenship. As a result, the Turkish government no longer recognized IRO protection for such individuals. They were now officially under the care of the Turkish government until they found employment. The Turkish Government tried to help a number of refugees, but at that time Turkey was a poor and agricultural country. It should be pointed out that well-educated people were always welcome.

Despite pressure from the ambassadors of France, the United States and the United Kingdom, the Turkish government did not join the IRO, due to its poor financial situation. The Turkish authorities realized what a valuable ally they had become for the West during the Cold War. It allowed them to set their own terms and stand by them, as well as adopt a pragmatic approach to policy-making.

\section{BIBLIOGRAPHY}

\section{Archival Materials}

Archives Nationales de France, Pierrefitte-sur-Seine, Archives of the I.R.O. - AJ 43.

The National Archives in London, Foreign Office - FO 371.

The Polish Institute and Sikorski Museum in London, Sztab NW i MSWojsk/MON, 1939-

$1948-$ A 12.

\section{Memories}

Sokolnicki, M., Ankarski dziennik 1943-1946, Londyn 1974.

\section{Books and Monographs}

Bayır, D., Minorities and Nationalism in Turkish Law, London-New York 2013.

Frantz, D., Collins, C., Death on the Black Sea: The Untold Story of the Struma and World

War II's Holocaust at Sea, New York 2003. 
Holborn, L. W., The International Refugee Organization: A Specialized Agency of the United Nations, London-New York-Toronto 1956.

Karpat, K., Studies on Ottoman Social and Political History, Leiden-Boston-Koln 2002.

King, C., O pótnocy w Pera Palace. Narodziny współczesnego Stambułu, transl. J. Hunia, Wołowiec 2016.

Shaw, S. J., Shaw, E. K., Historia Imperium Osmańskiego i Republiki Tureckiej 1808-1975, transl. B. Świetlik, Warszawa 2012.

The Turkish Minority in The People's Republic of Bulgaria, Sofia 1951.

Wolff, R. L., The Balkans in Our Time, Cambridge 1974.

\section{Articles}

Kostanick, H. L., "Turkish Resettlement of Refugees from Bulgaria, 1950-1953," Middle East Journal 1955, vol. 9, no. 1.

Sękowski, P., "Activity of the International Community in Europe after the Second World War within the Scope of the International Refugee Organization as a Model of the Aid Action towards Refugees," Securitologia 2017, no. 3.

Vasileva, D., "Bulgarian Turkish Emigration and Return," International Migration Review 1992, no. 26. 